\title{
Reversal of severe pulmonary hypertension with $\beta$ blockade in a patient with end stage left ventricular failure
}

\author{
J G Crilley, J H Dark, J A Hall
}

\begin{abstract}
A 52 year old man with severe chronic left ventricular failure (New York Heart Association class IV) was considered unsuitable for cardiac transplantation because of high and irreversible pulmonary vascular resistance (PVR). In an attempt to produce symptomatic improvement, metoprolol was cautiously introduced, initially at $6.25 \mathrm{mg}$ twice daily. This was slowly increased to $50 \mathrm{mg}$ twice daily over a two month period and continued thereafter. After four months of treatment the patient's symptoms had improved dramatically. His exercise tolerance had increased and diuretic requirements reduced to frusemide $160 \mathrm{mg} /$ day only. Assessment of right heart pressures was repeated and, other than a drop in resting heart rate, there was little change in his pulmonary artery pressure or PVR. His right heart pressures were reassessed showing a pronounced reduction in pulmonary artery pressure and a significant reduction in PVR, which fell further with inhaled oxygen and sublingual nitrates. He was then accepted onto the active waiting list for cardiac transplantation. A possible mechanism of action was investigated by assessing responses to $\beta$ agonists during treatment. Not only was there pronounced improvement in PVR but it was also demonstrated that $\beta$ receptor subtype crossregulation may have contributed to the mechanism of benefit.

(Heart 1998;80:620-622)
\end{abstract}

Keywords: $\beta$ blockers; transplantation; pulmonary hypertension; heart failure

We report the response to $\beta$ blockade in a patient with chronic left ventricular failure who was considered unsuitable for cardiac transplantation because of high irreversible pulmonary vascular resistance (PVR). After eight months of $\beta$ blockade, reinvestigation showed that his PVR had fallen and had become reversible such that he is now suitable for and awaiting cardiac transplantation. This beneficial effect of $\beta$ blockade on the pulmonary hypertension of left ventricular failure has not previously been described and widens further the growing indications for the use of $\beta$ blockers in heart failure. In addition, we investigated a possible mechanism of benefit by measuring the patient's haemodynamic responses to $\beta$ agonists before and during treatment.

\section{Case report}

The patient was a 52 year old man who presented to us in May 1993. He had had myocardial infarctions in 1986 and 1988. Significant left ventricular impairment had been documented by echocardiography in 1988 . He had been taking an ACE inhibitor since 1991. $\mathrm{He}$ was in New York Heart Association (NYHA) heart failure class I and had no angina. Echocardiography demonstrated a dilated poorly contracting left ventricle. He was able to exercise on a treadmill for seven minutes of a standard Bruce protocol, being limited by exhaustion, without chest pain or ischaemic ECG changes. Treatment with aspirin and lisinopril $(10 \mathrm{mg} /$ day) were continued.

In November 1994 he was referred again because of progressive symptomatic deterioration in breathlessness. He did not have chest pain. He now had NYHA class IV heart failure. Coronary angiography demonstrated diffuse triple vessel coronary artery disease. Left ventriculography showed an ejection fraction of $10 \%$. It was thought that surgical revascularisation would not be of benefit in the presence of such diffuse disease and in the absence of chest pain. Stress echocardiography and thallium scanning to reveal the presence of hibernating myocardium were therefore not performed. Right heart pressures revealed severe pulmonary hypertension (pulmonary artery pressure of $70 / 35 \mathrm{~mm} \mathrm{Hg}$ ) and a PVR of 440 dyn.s. $\mathrm{cm}^{-5}$ (table 1), which was not reversible with inhaled oxygen or sublingual nitrates. The patient's symptoms of breathlessness and peripheral oedema were barely controlled with frusemide $240 \mathrm{mg} /$ day and metolazone $2.5 \mathrm{mg} /$ alternate day in addition to digoxin $250 \mu \mathrm{g}$ /day, lisinopril $10 \mathrm{mg} / \mathrm{day}$, and warfarin. He was referred for cardiac transplantation but was not considered suitable because of his high and irreversible PVR.

Previous studies have suggested haemodynamic benefit from dobutamine ${ }^{1}$ and salbutamol $^{2}$ infusions in patients with heart failure. However, investigations using graded
Accepted for publication 26 June 1998 
Table 1 Pressures, measured using Swan-Ganz catheter, and cardiac output, measured via thermodilution method

\begin{tabular}{|c|c|c|c|c|}
\hline & November '94 & August '95 & December '95 & Fuly '96 \\
\hline Heart rate (beats/min) & 100 & 78 & 70 & 72 \\
\hline Aortic pressure $(\mathrm{mm} \mathrm{Hg})$ & $100 / 60$ & $101 / 50$ & $108 / 75$ & $135 / 85$ \\
\hline $\begin{array}{l}\text { Mean pulmonary artery } \\
\text { pressure }(\mathrm{mm} \mathrm{Hg})\end{array}$ & 45 & 42 & 34 & 34 \\
\hline $\begin{array}{l}\text { Mean pulmonary capillary } \\
\text { wedge pressure (mm Hg) }\end{array}$ & 30 & 27 & 21 & 19 \\
\hline $\begin{array}{l}\text { Pulmonary vascular resistance } \\
\left(\text { dyn.s. } \mathrm{cm}^{-5}\right)\end{array}$ & 440 & 307 & $257 \rightarrow 157^{\star}$ & $227 \rightarrow 145^{\star}$ \\
\hline Cardiac output $(1 / \mathrm{min})$ & 3.2 & 3.9 & 3.9 & 4.6 \\
\hline
\end{tabular}

${ }^{\star}$ Before and after inhaled oxygen and sublingual nitrates.

infusions of dobutamine $(0-16 \mu \mathrm{g} / \mathrm{kg} / \mathrm{min})$ and salbutamol $(0-4 \mathrm{mg} / \mathrm{kg} / \mathrm{min})$ over 15 minutes each with continuous pulmonary artery pressure monitoring suggested that they would be ineffective in reducing the patient's PVR to levels suitable for cardiac transplantation. In an attempt to produce symptomatic improvement, metoprolol was cautiously introduced, initially at $6.25 \mathrm{mg}$ twice daily. This was slowly increased to $50 \mathrm{mg}$ twice daily over a two month period and continued thereafter. After four months of treatment the patient's symptoms had improved dramatically. His exercise

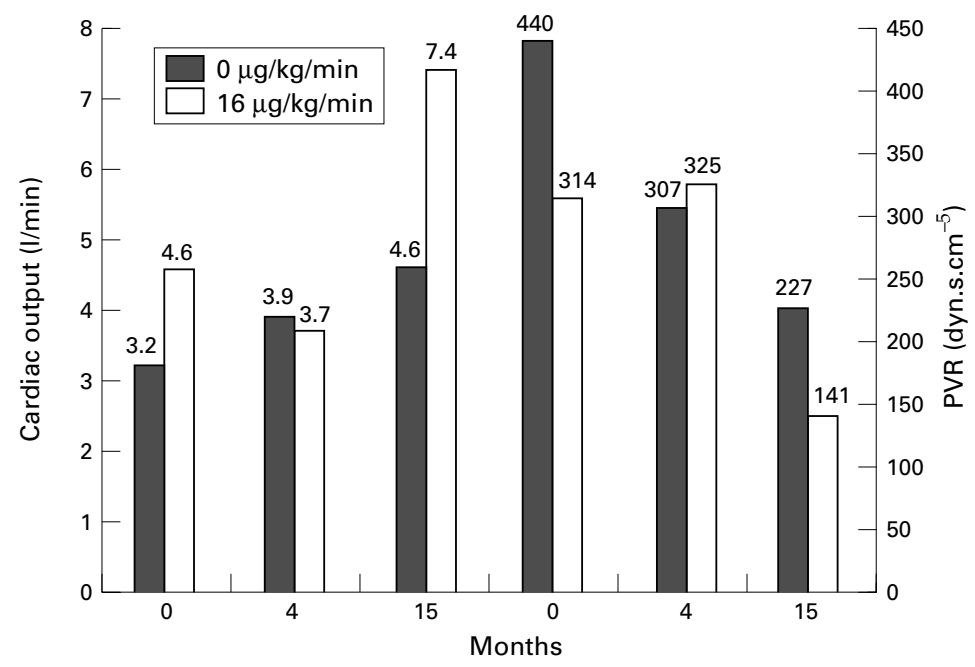

Figure 1 Cardiac output and pulmonary vascular resistance (PVR) with infusion of dobutamine at 0, 4, and 15 months after metoprolol.

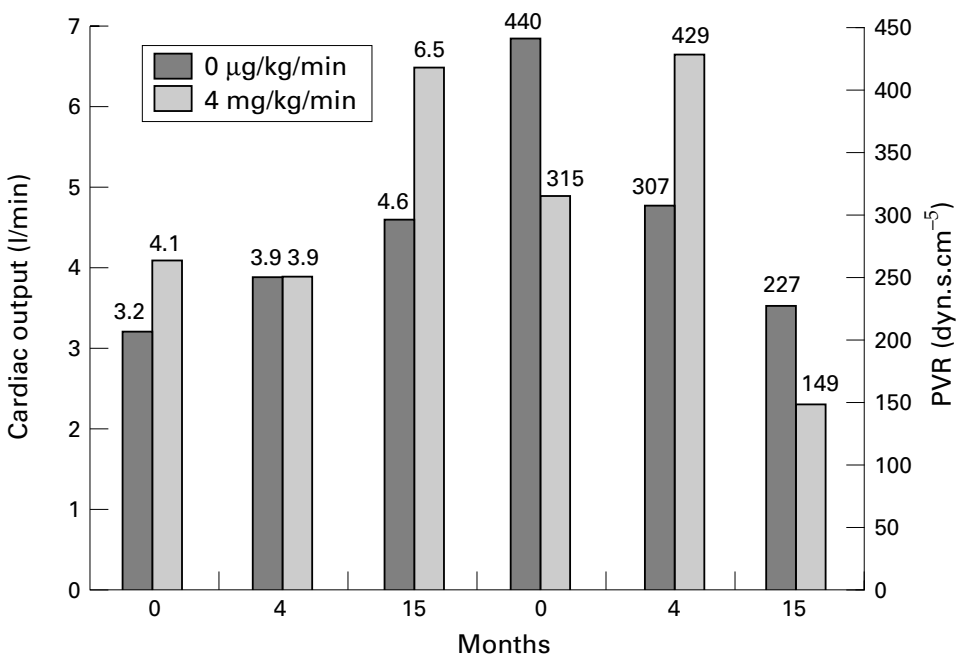

Figure 2 Cardiac output and pulmonary vascular resistance (PVR) with infusion of salbutamol at 0, 4, and 15 months after metoprolol. tolerance had increased and diuretic requirements reduced to frusemide $160 \mathrm{mg} /$ day only. Assessment of right heart pressures was repeated and, other than a drop in resting heart rate, there was little change in his pulmonary artery pressure or PVR (table 1).

In December 1995 his right heart pressures were reassessed (table 1); there was a pronounced reduction in pulmonary artery pressure $(48 / 24 \mathrm{~mm} \mathrm{Hg})$ and a significant reduction in PVR to 257 dyn.s.cm ${ }^{-5}$, falling to 145 dyn.s. $\mathrm{cm}^{-5}$ with inhaled oxygen and sublingual nitrates. He was accepted onto the active waiting list for cardiac transplantation.

\section{Discussion}

Attention has focused in recent years on the contribution of neurohormonal mechanisms to the development and progression of heart failure. Both activation of the renin-angiotensin system and the sympathetic adrenergic system occur in response to left ventricular dysfunction, and chronic activation of these systems may be further detrimental to myocardial function. ${ }^{3}$ Not only do catecholamine concentrations correlate with the severity of left ventricular dysfunction but they are independent risk factors of poor prognosis. ${ }^{4}$

Several studies-CONSENSUS (cooperative north Scandinavian enalapril survival study), ${ }^{5}$ SOLVD (studies of left ventricular dysfunction), ${ }^{6}$ VeHFT-II (verapamil in heart failure $)^{7}$ - have demonstrated both symptomatic improvement and mortality benefits from inhibition of the renin-angiotensin system in patients with heart failure. The effects of inhibition of the adrenergic system are less clear. A number of studies have shown $\beta$ blockers to have beneficial effects on morbidity. ${ }^{8}$ However, only one recent trial involving carvedilol has demonstrated any mortality benefits. ${ }^{10}$ The mechanism by which $\beta$ blockers exert their beneficial effects in heart failure is unclear. Differential modulation of $\beta$ receptor subtypes may be important. Cardiac $\beta 1$ receptor density is decreased in the failing heart, which renders it insensitive to $\beta 1$ stimulants both in vivo ${ }^{11}$ and in vitro. ${ }^{12}$ This downregulation of $\beta 1$ receptors has been attributed to high circulating concentrations of noradrenaline..$^{13}$ Cardiac $\beta 2$ receptor function in the failing heart is also altered and appears to be due to uncoupling of the $\beta 2$ receptor to the $G$ protein-adenylate cyclase complex. ${ }^{15} \mathrm{~A}$ decreased heart rate response to $\beta 2$ agonism in heart failure has been observed. ${ }^{16}$ Having assessed our patient's haemodynamic responses to dobutamine (a $\beta 1$ agonist) and salbutamol (a highly selective $\beta 2$ agonist) before metoprolol treatment, we were able to repeat these studies after $\beta$ blockade to investigate its effect on $\beta 1$ and $\beta 2$ responsiveness.

Before metoprolol, a graded infusion of dobutamine produced a modest rise in cardiac output and a modest fall in PVR (fig 1). After four months the response to dobutamine was blunted, there being no significant change during the infusion (fig 1). After 15 months, there was a profound increase in the sensitivity of the heart to the dobutamine infusion with a more pronounced rise in cardiac output and fall in 
PVR (fig 1). Responses to salbutamol showed a similar pattern (fig 2). Early clinical improvement at four months was associated with blunted responses to $\beta$ agonists and the persistence of high pulmonary artery pressures. It was only after sustained $\beta$ blockade that increased sensitivity to $\beta$ agonists was found with a concomitant improvement in pulmonary hypertension.

The enhanced response to $\beta$ agonists at 15 months could be explained by $\beta$ adrenoceptor subtype crossregulation by $\beta 1$ blockade with metoprolol. Previous studies have shown an increase in $\beta 2$ responsiveness after $\beta 1$ blockade in vitro ${ }^{17}$ and in vivo. ${ }^{18}$ This appears to be selective for cardiac $\beta 2$ receptors. ${ }^{19}$ The increase in dobutamine sensitivity might be due to the relatively poor selectivity of dobutamine for $\beta 1$ receptors in $\operatorname{man}^{20}$ - that is, dobutamine acting through $\beta 2$ receptors in a patient whose $\beta 2$ receptors have been sensitised by $\beta 1$ blockade. Heilbrunn et al demonstrated a similar increase in sensitivity to dobutamine after six months of metoprolol treatment in patients with idiopathic dilated cardiomyopathy. ${ }^{21}$ An intermediate stage of blunted responses has not previously been described.

The improvement in PVR is unlikely to result from any direct effect on pulmonary vascular $\beta 1$ receptors as there are no significant populations of $\beta 1$ receptors in the pulmonary arteries. It could be mediated via an alteration in pulmonary vascular $\beta 2$ receptor function caused by $\beta 1$ blockade. It is more likely that the fall in PVR was secondary to a long term lowering of pulmonary capillary wedge pressure. This possibility is supported by our finding of an improvement in pulmonary pressures coinciding with a fall in pulmonary capillary wedge pressure.

\section{CONCLUSION}

This case demonstrates that $\beta$ adrenoreceptor subtype crossregulation may be part of the beneficial effects of long term $\beta$ blockade in heart failure. It is clearly not the sole mechanism as clinical benefit was obvious at a time when the responses to $\beta$ agonists were blunted. At this stage the benefits could be due to preventing cytotoxic effects of catecholamines, anti-ischaemic effects or changes in myocardial metabolism. However, it is intriguing to find pronounced improvements in PVR coinciding with increased responses to $\beta$ agonists in the presence of continuing $\beta$ blockade. Further studies are needed to unravel the molecular mechanisms of $\beta$ blockade in heart failure but our case indicates a role for $\beta$ blocker treatment in patients with heart failure and severe "fixed" pulmonary hypertension.

1 Leier CV, Webel J, Bush CA. The cardiovascular effects of the continuous infusion of dobutamine in patients with severe cardiac failure. Circulation 1977;56:468-72.

2 Rotstein Z, Battler A, Rath S, et al. Acute haemodynamic and arrythmogenic effects of high-dose intravenous salbutamol in patients with chronic left ventricular dysfunction. Clinical Cardiology 1990;13:468-72.

3 Packer M. Pathophysiology of chronic heart failure. Lancet 1992;340:88-95.

4 Cohn JN, Levine TB, Olivari MT, et al. Plasma norepinephrine as a guide to prognosis in patients with chronic con-

5 The CONSENSUS Trial Study Group. Effects of enalapril on mortality in severe congestive cardiac failure: results of the cooperative north Scandinavian enalapril survival study (CONSENSUS). N Engl f Med 1982;316:1429-35.

6 The SOLVD Investigators. Effect of enalapril on survival in patients reduced left ventricular function and congestive heart failure. N Engl f Med 1991;325:293-302.

7 Cohn JN, Johnson G, Ziesche RV, et al. A comparison of enalapril with hydralazine-isosorbide dinitrate in the treatment of chronic congestive heart failure. $N$ Engl f Med 1991;325:303-10.

8 Waagstein F, Bristow MR, Swedburg K, et al. Beneficial effects of metoprolol in idiopathic dilated cardiomyopathy. Lancet 1993;342:1441-6.

9 CIBIS Investigators and Committees. A randomized trial of $\beta$ blockade in heart failure-the cardiac insufficiency bisoprolol study (CIBIS). Circulation 1994;90:1765-73.

10 Packer M, Bristow MR, Cohn JN, et al. The effect of carvedilol on morbidity and mortality in patients with chronic heart failure. N Engl f Med 1996;334:1349-55.

11 Bristow MR, Grinsburg R, Mihobe W, et al. Decreased catecholamine sensitivity and beta-adrenergic density in failing human hearts. $N$ Engl f Med 1982;305:205-11

12 Colucci WS, Denniss AR, Leatherman GF, et al. Intracoronary infusion of dobutamine to patients with and without severe congestive cardiac failure. F Clin Invest 1988;81: 1103-10.

13 Sandoval A, Gilbert EM, Rassmusen R, et al. Is $\beta 1$ receptor down-regulation in the failing human heart the result of cardiac-derived noradrenaline [abstract]. $7 \mathrm{Am}$ Coll Cardiol 1988;11:117A.

14 Rassmussen $\mathrm{R}$, Shah $\mathrm{P}$, Larrabee $\mathrm{P}$, et al. $\beta 1$ and $\beta 2$ receptor down-regulation associated with $\beta$ agonist administration in the failing human heart [abstract]. Circulation 1987;76: in -307 .

15 Bristow MR, Hershberger RE, Port DJ, et al. $\beta 1$ - and $\beta 2$-adrenergic receptor-mediated adenylate cyclase stimuation in non-failing and failing human ventricular myocardium. Mol Pharmacol 1989;35:295-303.

16 Steinfath M, Danielsen W, von der Leyen $\mathrm{H}$, et al. Reduced $\beta 1$ - and $\beta 2$-adrenoceptor-mediated positive inotropic effects in human end-stage heart failure. Br $\mathcal{F}$ Pharmacol 1992;105:463-9.

17 Hall JA, Kaumann AJ, Brown MJ. Selective $\beta 1-$ adrenoceptor blockade enhances positive inotropic responses to endogenous catecholamines mediated through B2-adrenoceptors in human atrial myocardium. Circ Res 1990;66:1610-23

18 Hall JA, Petch MC, Brown MJ. In vivo demonstration of cardiac $\beta 2$-adrenoreceptor sensitisation by $\beta 1$-antagonist treatment. Circ Res 1991;69:959-64.

19 Hall JA, Petch MC, Brown MJ. Intracoronary injections of salbutamol demonstrate the presence of functional $\beta 2$ salbutamol demonstrate the presence of functional $\beta 2-$
adrenoreceptors in the human heart. Circ Res 1989;65:54653.

20 Zerkowski HR, Ikezono K, Rohm N, et al. Human myocardial $\beta$ adrenoceptors: demonstration of both $\beta 1$ and $\beta 2$ adrenoceptors mediating contractile responses to $\beta$ agonists on the isolated right atrium. Naunyn Schmiedebergs Arch Pharmacol 1986;332:142-7.

21 Heilbrunn SM, Shah P, Bristow MR, et al. Increased $\beta$ receptor density and improved haemodynamic response to catecholamine stimulation during long-term metoprolol therapy in heart failure from dilated cardiomyopathy. Circulation 1989;79:483-90. 